\title{
On Dialogue Reading Teaching under the Background of New Curriculum
}

\author{
Kuai Xiuli
}

(Shangqiu Nornal University,Shangqiu Henan,476000,China)

\begin{abstract}
Chinese teaching. Make students the master of the classroom, which requires classroom teaching mode with communication interaction and common development. From the angle of dialogue theory, explore dialogue type reading teaching reform, and based on this, advance some tentative ideas and suggestions of improvement.
\end{abstract}

Key words: New curriculum standard;Reading teaching;Dialogue

Author introduction: Kuai XiuLi (1980 -), female, Henan, Shangqiu, lecturer, mainly engage in the study of basic theory of education.

Educational reform project: Shangqiu Normal College Education Teaching Reform Project in 2013: Dialogue Teaching in Teachers' Text Reading Strategy Research (number: 2013 jgxm50)

Compulsory Education Chinese Curriculum Standards (2011 Edition mentions twice "dialogue ": "Chinese teaching should be performed in the process of equal dialogue between teachers and students", "reading teaching is between students, teachers, textbooks contributors, and text dialogue process." This is not mentioned in all previous Chinese syllabuses. Under the background of new curriculum, promote dialogue teaching with its profound connotation; pursue the quality of the innovation and humanity care. This is a teaching form welcomed by teachers and students.

\section{THE PROBLEMS IN CURRENT READING TEACHING DIALOGUE}

\section{A. False dialogue in class}

Formalized, false dialogue refers to the seemingly dialogue in the process of teaching forms with no substantial contents and real brush. In real sense, the dialogue is the form and decoration of classroom, and has not educational or weak teaching effect. In other words, they are just for the sake of dialogue and conversation, with only the active atmosphere but thinking, and cannot promote the development of students' deep thinking.

Make a little comparison, we can discover that in some cases "question" teacher wants to discuss is not necessarily the problem students most interested in or want to explore. It is certain problem teachers early prepared and they are most interested in or want to explore, or problems curriculum standard has stipulated early or prompted. This conversation cannot really stimulate students' learning enthusiasm, and is likely to cause the student resistance against the teacher. 


\section{B. Teaching devoted to dialogue and lack of necessary profound}

Multilateral interaction and communication between teachers and students is one of the dialogue qualities of teaching. Dialogue teaching takes it as an important attributes and their characteristics. Stress and dialogue is a real teaching pursuit under the background of new curriculum reform. But it must be clear that dialogue and teachers teaching are not a contradiction and opposite. Dialogue teaching does not reject teacher's teaching, on the contrary, stress and pursue dialogue cannot depart from teachers' wonderful, deep and necessary teaching.

Otherwise, dialogue is superficial and very likely lack of profound. But at this point, real dialogue teaching practice is not given sufficient attention and understanding. Overemphasis and devotion to dialogue, lack of or exclude teacher lecturing teaching is still very common.

\section{Pay attention to generation painstakingly, lost the basic goal of teaching}

Compared with traditional teaching's single default target, new courses strengthen the awareness of the generative in the process of teaching goal. Dialogue teaching takes the generative goal as an important goal orientation of classroom design. But this does not mean that the dialogue teaching reject or abandon some basic default target, because this is the bottom line of teaching efficiency. In other words, dialogue teaching should give full play to teachers' teaching tact, develop and utilize generative curriculum resources, and keep teaching bottom line, and complete the basic goal of teaching. However, the reality of dialogue teaching is not optimistic, and is often deliberately pay attention to the phenomenon generated and lost the basic teaching goal.

\section{THE FORMING CAUSES OF THE PROBLEMS IN CURRENT DIALOGUE TEACHING IN READING TEACHING}

Aiming at the problems revealed in dialogue teaching practice, we have to face the reality and reveal the cause of the problem. This is the correct attitude of dialogue teaching and research to ensure the healthy and benign development dialogue teaching practice. The study found that the main reasons of the problems exposed in dialogue teaching practice are roughly the following:

\section{A. Argument or debate, discussion, conversation or dialogue}

In general, argument or debate, discussion, conversation or q\&a, contain an element of "dialogue", or are likely to be a way of "dialogue", but they are not completely equal to "dialogue": "discussion" must be determined by both or all parties around a theme to carry out, finally come to some conclusions. "Debate" is also the same. When faced with numerous points of view, "argument" or "debate" emphasize the analysis, make every effort to overcome with a perspective or refute the other one or several views. Like playing table tennis, go to both parties, the purpose is to let his side to win or at least have the upper hand. "Dialogue", on the other hand, sincerely hopes collision, agitate and blending between a variety of opinions or suggestions for the most radical and the most free and unfettered exchange and communication between people.

If equate dialogue with discussion, argument or debate, conversation or question and answer, it is easy to fall into such understanding erroneous zone, namely: whatever style of conversation in class is the classroom dialogue. "Only when" live "in the process is to better achieve the goal, the "live" is 
meaningful, or it is just a class show, rather than classroom teaching, and results in 'style class, empty students mind".

\section{B. Dialogue is generated}

Generative is a basic attribute and outstanding characteristic of dialogue teaching, so that people always associate dialogue teaching and construct generation, and even think that dialogue is generated, and dialogue teaching is generated. In fact this is a big misunderstanding. Why will have this understanding? We believe that this is the result of a kind of people like go to extremes. In people's view, the traditional teaching goal was preset, and ignored that classroom is a complicated organic system.

Since the dialogue teaching is the reform of traditional teaching, and then use generating target to replace the preset goal naturally becomes the choice of dialogue teaching. In fact, in dialogue teaching, generation and default are not antagonistic, and both are mutually complementary relationship. Classroom dialogue teaching pays attention both to this complex system, uses generative resources in the classroom, at the same time pays attention to teaching benefits requests, and preset goal the teaching bottom line.

\section{Dialogue is the antithesis of teaching}

In some people's mind, dialogue is the antithesis, contradictory of teaching. I'm afraid teachers holding this view are still not in the minority. When experts comes to the new curriculum, often inadvertently hinted that teaching is the antithesis of interaction, dialogue. Besides that, in the words describing new curriculum classroom teaching, we can also feel the invisible rejection of teachers' teaching. Words always describe as: "a lesson ends in the interaction of teachers and students, cooperation, discussion and question and experience." Between the lines, there is no wonderful teachers' teaching and sincere precept.

\section{Teacher narrow knowledge is difficult to deal with various problems put forward by the} students in the classroom

Narrow knowledge is at present the common fault of a lot of primary school teachers. Under this situation, in the face of various problems proposed by the teaching of middle school students, only take strategies to go round it. Thus, many false dialogues have a great association with the teachers' narrow range of knowledge in the classroom.

\section{THE IMPLEMENTATION STRATEGY OF DIALOGUE READING TEACHING}

\section{A. Open}

Open refers to the choice of teaching content should be geared to the needs of all students.

The former teaching pursued the principle of "efficiency first", so in the choice of teaching content, usually took medium level students' cognitive ability for reference point. As for the middle and lower levels students, the teacher more took "laissez faire", thus the result was: the teaching activities were unfair from the starting point, gave up the responsibility for part of the student's education, but also impaired the initiative and enthusiasm of them to participate in teaching activities. In such a teaching situation, it is difficult to find real meaning dialogue, even if there is the so-called "dialogue", it is also in a position of good students, teachers and the text. The edge status students in the teaching content 
were very hard to find their own voice, for them, the content from beginning to end was closed, exclusive.

This choice of teaching content is not consistent with the spirit of dialogue teaching. Dialogue teaching is various, both at the dialogue between teachers and students, students and dialogue between teachers and text, students and text. But what kind of type of dialogue, it is to enhance mutual understanding and common development between teachers and students, and more importantly, for each student's independent, free and harmonious growth. If the text (content) from the beginning exclude part of students, the teaching process is bound to be reduced to a "non-dialogue", or "oppressive", namely through the filter text (content), part of the students become " words barnyard", other students take "discourse hegemony", and the latter voice gains at the expense of the loss of the former voice. Thus it is conceivable that the significance of open teaching content in dialogue teaching.

\section{B. Understanding}

Here the "understanding" mainly refers to the teaching content can be understood by students. If teaching content is fully known to the students, it has no comprehension sense; on the other hand, if teaching content is complete strange to students, it is impossible to be understood. Dialogue teaching, therefore, requires the teaching content should have a certain understanding, which is between total strangers and fully familiars. In fact, it is this understanding gives all possibilities to effective teaching. In general, "proximal development zone" concept implication is such an education belief that education should be aimed at the tomorrow development of the students, therefore, teaching should walk in front of the development of the students, and should strive to reflect the possibility of student development. Teachers in teaching content, must pay attention to students' existing state of development, and determine the development level of the students. In a certain sense, the former shows the teaching contents familiarity for students; the latter reflects the teaching content new space for students. Only when teachers present teaching content appear on two kinds of development level, or between familiarity and strangeness, can teaching effectiveness and the development truly appear.

\section{Participation}

Participation refers to the possibility the teaching content stimulates the student to participate in the dialogue. Teaching process of dialogue is the process of active participation of students. However, not all of the teaching content has the structure to stimulate the student to participate in the dialogue.

Dialogue is a kind of mental state built up by teachers and students interact with the text, which not only has the intellectual identity, but more learning motivation, attitude and emotional awakening. Therefore, teacher's choice of teaching content should not only consider the students' cognitive development levels, but should focus on students' interests, hobbies, motivation level, personality, etc. In dialogue teaching, if there is no corresponding affective input, students cannot really involve in the process of dialogue. Affective commitment may be related to students' desire to explore in the teaching content, may also be student's emotional resonance to the content of teaching, and may be student's acute awareness of the teaching content.

The dialogue is a kind of participation, a two-way or multi-way teachers and students' participation. This may be implicit, but more is needed by explicit behavior to be demonstrated. To start dialogue, first of all, there are two or more than two main bodies, and there are differences in the main bodies' 
horizons. If the two sides only say "the vernacular", or not by each other's perceived way to express their own opinions, dialogue is impossible to produce.

Therefore, dialogue is not only a concept input, but action involved. This means that dialogue teaching reflecting spirit necessarily and intrinsically contains the realistic condition of students to participate in the dialogue. Presentation of content, for example, is realized directly by students' activities (such as text reading, film and television viewing, role playing, multimedia presentation, handmade, etc.).

Dialogue type reading teaching has characteristics such as equality, interaction, humanistic, combined with the humanity and inspiring aesthetic of Chinese curriculum itself, actively carry out this teaching model can improve the students' participation enthusiasm and interest of reading. In the process of dialogue, students not only improve listening and speaking skills, communication skills and explore the ability of cooperation, but also promote personality and aesthetic sentiment ascension, promote students learning to learn, live life, and form bright personality. In addition, dialogue is a dynamic process. This process is the text meaning generation, improvement of teachers' ability, and students study progress. it is also a process which lets all dialogue subject realize the innovative development, therefore, dialogue type reading teaching is a very worth studying subject.

\section{REFERENCES:}

[1](British) David Cuny. On dialogue. [M]. Beijing: Education Science Press, 2004.

[2] [U.S.] William Weilun. Li Senzhu translation. The effective teaching decision making [M]. Beijing: Education Science Press, 2005.

[3] [British] Saran, [Germany] Nai Selma Ed. Mind: theory and practice of Socrates' dialogue teaching method [M]. Beijing: Education Science Press, 2010.

[4] Wang Songtao. The way of dialogue education: educators do consciously dialogue [M]. Beijing: Education Science Press, 2010.

[5] JinYule. Dialogue teaching. [M]. Chengdu: Sichuan Education Press, 2006.

[6] Wang Xianghua. Dialogue education pergamon [M]. Beijing: Education Science Press, 2009. 